\title{
STUDY OF 30 CASES OF HISTOPLASMOSIS OBSERVED IN MATO GROSSO DO SUL STATE, BRAZIL
}

\author{
Marilene Rodrigues CHANG(1), Cleison Ledesma TAIRA(2), Anamaria Melo Miranda PANIAGO(3), Deborah Ledesma TAIRA(2), \\ Rivaldo Venâncio CUNHA(3) \& Bodo WANKE(4)
}

\begin{abstract}
SUMMARY
Thirty cases of histoplasmosis observed at the University Hospital of the Federal University of Mato Grosso do Sul (HUUFMS) from January 1998 to December 2005 are reported. Most (83.3\%) of the patients were men, average 33.4 years old, 63.3\% of them were born and living in Mato Grosso do Sul and 83.3\% presented AIDS as an underlying disease. In almost all cases (96.7\%) the disease occurred in its disseminated form and the most frequent clinical manifestations were: fever (83.3\%), weight loss $(70.0 \%)$, cough $(63.3 \%)$, hepatomegaly and splenomegaly $(40.0 \%)$, and lymph node enlargement $(36.7 \%)$. The laboratory diagnosis was obtained in 29 patients by isolation of Histoplasma capsulatum from various clinical specimens cultivated in Sabouraud dextrose and brain heart infusion agar and in 16 patients the fungus was observed by direct microscopy of Giemsastained smears. The observed mortality was $40 \%$. This is the first report in the literature of the occurrence of histoplasmosis in Mato Grosso do Sul State.
\end{abstract}

KEYWORDS: Histoplasmosis; Histoplasma capsulatum; AIDS; Mato Grosso do Sul (Brazil).

\section{INTRODUCTION}

Classic human histoplasmosis is an endemic systemic mycosis caused by the dimorphic fungus Histoplasma capsulatum var. capsulatum, which occurs in its mycelial form during its saprophytic life cycle and in cultures at room temperature, and in its yeast form in infected tissues and in cultures incubated at $35^{\circ} \mathrm{C}^{8}$. This disease has been diagnosed in more than 60 countries on every continent, the greatest concentration of cases being in the Central/Eastern portions of the United States and the greater part of Latin America ${ }^{6}$. In Brazil, it has been reported most frequently in the Southeast ${ }^{2,8}$ and South ${ }^{12,16}$ regions, with scarce reports and studies in the Central-West region.

The etiological agent grows as a saprobe in nature, mainly in places with high concentration of bat and/or bird excreta such as caves, old and/or abandoned houses, old chicken coops; in short, anywhere that these animals roost or find shelter. In such contaminated places the fungus grows in its mycelial form and produces abundant microconidia, which disperse in the air and may be inhaled by humans and many other susceptible animals ${ }^{8}$.

Most of the infections in humans evolve asymptomatically, spontaneously regressive. The main clinical forms are: i) acute pulmonary; ii) chronic pulmonary (cavitary); iii) disseminated (acute, subacute and chronic subtypes); iv) opportunistic, mainly in AIDS patients; and v) immunologically mediated (histoplasmoma, fibrosing mediastinitis and ocular syndrome $)^{8,9}$.

Before the advent of AIDS, the disseminated forms of histoplasmosis mainly affected individuals at extreme ages (less than one or more than 50 years old), immunodepressed individuals, such as those with neoplastic diseases (mainly leukemia and lymphoma) or users of immunosuppressive therapy, especially corticosteroids ${ }^{2}$. Since 1980, the occurrence of disseminated histoplasmosis has become common among patients with AIDS, being considered a defining disease of this syndrome ${ }^{3,8}$.

The present study describes 30 cases of histoplasmosis diagnosed at the Laboratory of Mycology of HU-UFMS, focusing on the early laboratorial identification of $H$. capsulatum, especially in immunocompromised patients, in whom it usually is fatal if not diagnosed and properly treated.

\section{MATERIALS AND METHODS}

DATA COLLECTION: The data were obtained from 30 patients diagnosed with histoplasmosis at the HU/UFMS, from January 1998 to December 2005. The HU/UFMS is the leading AIDS treatment center in the city of Campo Grande, Mato Grosso do Sul State, Brazil. Each questionnaire was analyzed in terms of medical records of patients, including clinical and epidemiological data. 
MYCOLOGICAL DIAGNOSIS: The diagnosis of histoplasmosis was made by: i) direct microscopic exam of Giemsa-stained smears, and/or ii) isolation of H. capsulatum in cultures. The fungus was isolated from clinical specimens such as bone marrow, blood, sputum, bronchoalveolar lavage fluid, urine and biopsies from various tissues, including lymph nodes, skin lesions and gastric mucosa. Blood samples were incubated at Bactec System (Becton Dickson). All the clinical specimens were inoculated on Sabouraud dextrose agar and incubated at $30^{\circ} \mathrm{C}$ and brain heart infusion agar (BHI-DIFCO) at $35^{\circ} \mathrm{C}$ for six to 12 weeks. Samples of suspected fungal growth compatible with $H$. capsulatum at room-temperature $\left(30^{\circ} \mathrm{C}\right)$ cultures were microscopically observed for the presence of suggestive macroconidia and microconidia using lactophenol cotton blue stain. The definitive diagnosis was obtained when dimorphism was demonstrated by the growth of yeastform cells in BHI at $35^{\circ} \mathrm{C}$.

STATISTICAL ANALYSIS: The clinical and epidemiological data were collated together with the laboratorial results using Excel software, and subsequently analyzed using the program Epi Info Version 3.2.2 (CDC software).

This study was approved by ethics committee of UFMS.

\section{RESULTS}

Of the 30 patients studied, 25 were male (83.3\%), ranging from 13 to 58 years old, average of 33.4 years. Most of the patients were from the Mato Grosso do Sul State (90\%). Of these, 19 were also born in Mato Grosso do Sul (63.3\%). Only eight patients (26.7\%) reported an epidemiological history suggestive of histoplasmosis, such as having a chicken coop in the backyard of their home, having visited caves or having worked in rural areas.

A total of $25(83.3 \%)$ presented the disseminated form associated with AIDS. Fourteen cases had other AIDS-related opportunistic infections: mucosal candidiasis in 13 cases, tuberculosis in two cases and pneumocystosis in one case. CD4 cell counts and viral burdens were not available in the medical records of the patients.

The remaining patients did not present any underlying disease: three cases with the subacute disseminated form, one case with the chronic disseminated form, and one case with the acute pulmonary form.

The most frequent signs and symptoms were: fever (83.3\%), weight loss $(70.0 \%)$, coughing $(63.3 \%)$ asthenia $(63.3 \%)$, enlarged liver and spleen $(40.0 \%)$, enlarged lymph nodes $(36.7 \%)$, diarrhea $(46.7 \%)$ and skin lesions (16.7\%). Two patients presented involvement of the gastric mucosa, histologically diagnosed through biopsy of the lesion observed by endoscopy. In one case, the patient presented osteolytic lesions in the bones of the hands and feet with cutaneous pus draining fistulae, from which the pathogen was isolated.

Microscopic exam of Giemsa-stained smears revealed the presence of intracellular yeasts in $16(64.0 \%)$ of the 25 cases in which the exam was made. In three patients the fungus was observed in a sample of peripheral blood upon realization of a hemogram. Clinical specimens obtained from 30 patients were cultivated and $H$. capsulatum was isolated from 29 of them, indicating a very high sensitivity (96.7\%).
Bone marrow was the clinical specimen from which isolation was most frequently obtained $(n=12)$, followed by blood culture $(n=7)$, skin biopsy $(n=5)$, lymph-node biopsy $(n=4)$, sputum $(n=3)$, bronchoalveolar lavage $(n=3)$ and urine $(n=1)$. In three patients, the fungus was observed in more than one clinical specimen.

Twelve patients died, all of them carriers of the HIV virus and most of them presenting other concomitant opportunistic diseases.

\section{DISCUSSION}

Cases of histoplasmosis in Brazil have been most frequently observed in the Southeast ${ }^{2,8}$ and South ${ }^{12,16}$ regions. In the other regions, there have been only sporadic reports ${ }^{14}$. An epidemiological survey carried out in the county of Sidrolândia, located $60 \mathrm{~km}$ from Campo Grande, the capital of the Mato Grosso do Sul State, found a $9.7 \%$ rate of reactivity to histoplasmin ${ }^{1}$, suggesting an area of low endemicity. Most $(63.3 \%)$ of the patients in the present study were native-born residents of the Mato Grosso do Sul State. This, associated with the fact that one of these cases presented the acute pulmonary form, demonstrates, for the first time, the occurrence of symptomatic histoplasmosis in this Brazilian State.

Similar to the findings of other researchers, such as ROCHA \& SEVERO $^{11}$ and LEIMANN ${ }^{8}$, in this study most of the patients with histoplasmosis were young males, which corresponds to the profile of AIDS patients in Mato Grosso do Sul. In terms of profession, no occupational risk was observed, with the exception of seven patients who visited caves, possessed a chicken coop near their homes or worked in rural areas.

The most frequent clinical manifestations observed in the patients corresponded to those of disseminated histoplasmosis, the predominant form in the present and in previously published reports ${ }^{3,8}$; these symptoms include fever, weight loss, enlarged liver and spleen, and enlarged lymph nodes. In immunocompromised patients histoplasmosis generally occurs as an opportunistic disease, with dissemination to various organs ${ }^{3,16}$. Dissemination to the skin, known to be very frequent among patients with AIDS ${ }^{15}$, was observed in only $16.7 \%$ of our cases. Involvement of bones, as in one of the cases presented here, has rarely been described in the literature ${ }^{10}$.

Involvement of the bone marrow, an organ of the phagocytemonocyte system, was demonstrated in 12 cases by isolating $H$. capsulatum in cultures from aspirated bone marrow. We emphasize the importance of culturing this specimen for the diagnosis of mycosis, and in particular for the differential diagnosis of visceral leishmaniasis, which is endemic in the Mato Grosso do Sul State.

The laboratory diagnosis is limited insofar as direct mycological examination of fresh preparations does not evidence the agent; for this reason, staining techniques such as Giemsa, PAS and Grocott-Gomori methenamine silver (GMS) ${ }^{6}$ are recommended. The finding of singlebudding yeast-form cells is strongly suggestive, especially when found intracellularly, since this can clarify the clinical case and allows an immediate startup of therapy. However, the definitive diagnosis should be based on successful culturing of the agent and its posterior identification, which generally takes 15 to 20 days. Other laboratory 
tests, such as serological exams, complement fixation assays, precipitation tests, latex particle agglutination tests, agar-gel double immunodiffusion (ID) tests and radioimmunoassay have also been used $^{4,7}$. In large parts of Brazil, the ID test is the most used routinely.

Histoplasmosis associated with AIDS often leads to death, even when treated. The high mortality rate $(40.0 \%)$ found in the 25 HIVpositive patients in the present study was similar to that reported in the study by KARIMI et $a l^{5}$. These high mortality rates reinforce the importance of an early and precise laboratory diagnosis. A properly conducted clinical investigation coupled with effective communication between clinicians, pathologists and mycologists is essential for early diagnosis, leading to a focused and effective treatment of this important systemic mycosis.

\section{RESUMO}

\section{Estudo de 30 casos de histoplasmose no Estado de Mato Grosso do Sul, Brasil}

Foram estudados 30 casos de histoplasmose observados no estado de Mato Grosso do Sul - HU-UFMS, no período de janeiro de 1998 a dezembro de 2005. Os pacientes eram, na maioria, homens $(83,3 \%)$ jovens (média de 33,4 anos de idade), naturais e procedentes de Mato Grosso do Sul $(63,3 \%)$ e tinham AIDS como principal doença subjacente $(83,3 \%)$. Houve predomínio da forma disseminada $(96,7 \%)$ e as manifestações clínicas mais freqüentes foram: febre $(83,3 \%)$, emagrecimento $(70,0 \%)$ tosse $(63,3 \%)$, hepatoesplenomegalia $(40,0 \%)$ e linfonodomegalia $(36,7 \%)$. O diagnóstico laboratorial foi obtido por exame microscópio direto de esfregaços corados pela técnica de Giemsa, em 16 pacientes, e isolamento de $H$. capsulatum em cultivo nos meios de agar Sabouraud dextrose e agar infusão de cérebro e coração, de materiais diversos, em 29 pacientes. A letalidade observada foi de $40 \%$. O trabalho apresenta, pela primeira vez na literatura, a ocorrência de histoplasmose-doença no Estado de Mato Grosso do Sul.

\section{ACKNOWLEDGEMENTS}

We are very grateful to the physician residents and nurses from the Hospital Universitário for assistance to the patients and technical support.

Financial support: This research was supported by FUNDECT/MS - 41/100.017/2005.

\section{REFERENCES}

1. AGUIAR, E.S.A. - Prevalência de infecção pelo Histoplasma capsulatum e pelo Paracoccidioides brasiliensis em escolares, granjeiros e população indígena na região de Sidrolândia, MS. Campo Grande, 2000. (Dissertação de mestrado Universidade Federal de Mato Grosso do Sul/ FIOCRUZ).
2. BORGES, A.S.; FERREIRA, M.S.; SILVESTRE, M.T.A.; NISHIOKA, A.S. \& ROCHA A. - Histoplasmose em pacientes imunodeprimidos: estudo de 18 casos observados em Uberlândia, MG. Rev. Soc. bras. Med. trop., 30:119-124, 1997.

3. JOSEPH WHEAT, L.; CONNOLLY-STRINGFIELD, P.A.; BAKER, R.L. et al. Disseminated histoplasmosis in the acquired immune deficiency syndrome: clinical findings, diagnosis and treatment, and review of the literature. Medicine, 69: 361373,1990 .

4. JOSEPH WHEAT, L. - Current diagnosis of histoplasmosis. Trends Microbiol., 11: 488494, 2003.

5. KARIMI, K.; WHEAT, L..J.; CONNOLLY, P. et al. - Differences in histoplasmosis in patients with acquired immunodeficiency syndrome in the United States and Brazil. J. infect. Dis., 186: 1655-1660, 2002.

6. KWON-CHUNG, K.J. \& BENNETT, J.E. - Histoplasmosis. In: KWON-CHUNG, K. J. \& BENNETT, J.E. Medical mycology. Philadelphia, Lea \& Febiger, 1992. p. 464513.

7. LACAZ, C.S.; PORTO, E.; MARTINS, J.E.C.; HEINS-VACCARI, E.M. \& MELO, N.T. - Tratado de micologia médica. São Paulo, Sarvier, 2002.

8. LEIMANN, B.C.Q.; PIZZINI, C.V.; MUNIZ, M.M. et al. - Histoplasmosis in a Brazilian center: clinical forms and laboratory tests. Rev. iberoamer Micol., 22: 141-146, 2005

9. NEGRONI, R. - Histoplasmose. In: VERONESI, R. \& FOCACCIA, R., ed. Tratado de infectologia. São Paulo, Atheneu, 2002. p. 1140-1149.

10. QURAISHI, N.A.; DAVIDSON, R.N.; STEELE, N. \& GRAND F. - Histoplasmosis as the cause of a pathological fracture. J. Bone Jt Surg., 85: 732-733, 2003.

11. ROCHA, M.M. \& SEVERO, L.C. - Histoplasmose disseminada em pacientes com síndrome de imunodeficiência adquirida (SIDA). Estudo de 25 casos. Rev. Inst. Med. trop. S. Paulo, 36: 167-170, 1994.

12. SEVERO, L.C.; OLIVEIRA, F.M.; IRION, K.; PORTO, N.S. \& LONDERO, A.T. Histoplasmosis in Rio Grande do Sul. Brazil: a 21-year experience. Rev. Inst. Med. trop. S. Paulo, 43: 183-187, 2001.

13. SEVERO, L.C.; LEMOS, A.C.M. \& LACERDA, H.R. - Mediastinal histoplasmosis: report of the first two Brazilian cases of mediastinal granuloma. Rev. Inst. Med. trop. S. Paulo, 47: 103-105, 2005.

14. TALHARI, S.; SOUZA-CUNHA, M.G.; SCHETTINI, A.P.M. \& TALHARI, A. - Deep mycosis in Amazon region. Int. J. Derm., 7: 481-484, 1988.

15. TOBÓN, A.M.; AGUDELO, C.A.; ROSERO, D.S. et al. - Disseminated histoplasmosis: a comparative study between patients with acquired immunodeficiency syndrome and non-human immunodeficiency virus-infected individuals. Amer. J. trop. Med. Hyg., 73: 576-582, 2005.

16. UNIS, G.; OLIVEIRA, F.M. \& SEVERO, L.C. - Disseminated histoplasmosis in Rio Grande do Sul. Rev. Soc. bras. Med. trop., 37: 463-468, 2004.

Received: 7 April 2006

Accepted: 14 August 2006 